\section{Water deficit increases the frequency of hybrid citrus with polyembryonic female parents}

\section{Lucas Aragão da Hora Almeida ${ }^{1}$, Dayse Drielly Souza Santana- Vieira ${ }^{1}$, Nayara de Almeida Santos ${ }^{2}$, Ivan Schuster ${ }^{3}$, Walter dos Santos Soares Filho ${ }^{4}$, Maurício Antônio Coelho Filho ${ }^{4}$ and Abelmon da Silva Gesteira ${ }^{1,4^{*}}$}

\begin{abstract}
The aim of this study was to develop a methodology that uses water deficit induction to increase the frequency of hybrids in Citrus varieties that have a high and an intermediate level of polyembryony, respectively. The experiment examined the 'Sunki Tropical' mandarin and 'Rangpur Santa Cruz' lime genotypes at three water stress intensities: 20,40 and $100 \%$ of the pot capacity (PC). The generated fruits were harvested, and the seeds were counted. After germination, the number of nucellar and hybrid seedlings was determined. For 'Rangpur Santa Cruz' lime genotype, the highest hybrid frequency generated was $64.2 \%$, which occurred at a PC of $40 \%$ and exceeded by $12 \%$ that occurring at a PC of $100 \%$. For 'Sunki Tropical' mandarin, the highest observed hybrid frequency was $21.75 \%$, which occurred at a PC of $20 \%$ and was more than double the hybrid frequency of $8.57 \%$ observed at $100 \%$ of the $P C$.
\end{abstract}

Key words: Plant breeding, rootstock, apomixis, drought, Citrus spp.

\section{INTRODUCTION}

Most plant species are perpetuated by zygotic embryogenesis, but some, such as citrus, are able to spread naturally from somatic cells, a phenomenon called apomixis (Nakano et al. 2013) and by rooting of stem cuttings, keeping, in both cases, genotypic characteristics of the original plant (Siviero et al. 2003). Polyembryony is a type of apomictic reproduction that is responsible for generating more than one embryo per seed (Chen et al. 2008, Soares Filho et al. 2014). This peculiarity allows the multiplication of interesting genotypes, especially in the case of rootstocks, by generating clones formed from the nucellar tissue of the mother plant.

The significant geographic spread of citrus (Citrus L. and related genera) and increased incidence of diseases, pests and climate change plaguing this culture, direct efforts to the development of cultivars tolerant and/or resistant to stress of biotic and abiotic nature. Among the solutions is the diversification of rootstocks, especially those from crosses with Poncirus trifoliata (L.) Raf., an important species in the development of new varieties because of their tolerance to certain biotic stresses (Ollitrault and Navarro 2012).

The progeny obtained from crosses involving $P$. trifoliata have the potential to generate rootstocks capable of reducing the size of scion, in addition to enabling
Crop Breeding and Applied Biotechnology 18: 47-54, 2018 Brazilian Society of Plant Breeding. Printed in Brazil http://dx.doi.org/10.1590/1984$70332018 v 18$ n1a7

\footnotetext{
*Corresponding author: E-mail: abelmon.gesteira@embrapa.br
}

Received: 28 November 2016 Accepted: 07 May 2017

${ }^{1}$ Universidade Estadual de Santa Cruz, Centro de Genética e Biologia Molecular, Departamento de Biologia, 45.662-900, Ilhéus, Bahia, Brazil

${ }^{2}$ Universidade Federal do Recôncavo da Bahia, Departamento de Biologia, 44.380-000, Cruz das Almas, Bahia, Brazil ${ }^{3}$ Cooperativa Central de Pesquisa Agrícola, Zona Rural, 85.813-450, Cascavel, Paraná, Brazil

${ }^{4}$ Embrapa Mandioca e Fruticultura, 44.380000, Cruz das Almas, Bahia, Brazil 


\section{LAH Almeida et al.}

disease resistance, the production of high quality fruit and tolerance to cold, alkalinity, salinity and drought (Passos et al. 2006, Grosser et al. 2007, Hussain et al. 2012, Castle et al. 2006). The good performance of hybrid rootstocks generated from crosses with $P$. trifoliata can not only produce stable and productive orchards but also enable their expansion into non-producing regions, with positive effects on the income of growers. In addition, hybridizations with $P$. trifoliata are routine because this species is associated with a dominant, readily evident, morphological marker, which is the presence of leaves with trifoliate blades, allowing the early identification of zygotic seedlings derived from crosses with female parents whose leaf blades are simple (Soares Filho et al. 2014).

The process of obtaining hybrids is restricted by the high polyembryony of certain female parents, the high heterozygosity that is common to most citrus species, and the long period needed to assess the generated individuals (Soares Filho et al. 2014). Referring to polyembryony, the presence of many nucellar embryos in the same seed and their subsequent competition with the zygotic embryo hinder the survival of the zygotic embryo and may lead to the elimination of individuals with potential for agronomical use. This phenomenon is evident in female parents with otherwise outstanding agronomic qualifications as rootstock, such as the 'Sunki' mandarin [C. sunki (Hayata) hort. ex Tanaka] Tropical selection, whose polyembryony approaches $100 \%$, unlike the common 'Sunki', which presents a low degree of polyembryony, less than $20 \%$ (Soares Filho et al. 2002). This situation limits the recovery of hybrids (Soares Filho et al. 2014) and thereby constructs a barrier to the development of new rootstocks.

The 'Sunki Tropical' mandarin plant has advantages over the common 'Sunki' mandarin regarding its use as rootstock, including more seeds per fruit and high polyembryony (Soares Filho et al. 2002). These characteristics, which are associated with good drought tolerance and resistance to Phytophthora gummosis according to observations made in commercial field orchards, show a possible superiority of 'Sunki Tropical' over the common 'Sunki' in the generation of good varieties of rootstock by hybridization. In this context, it is of paramount importance to develop methods to control the high polyembryony rates recorded in 'Sunki Tropical' and other varieties of citrus, such as 'Cleopatra' mandarin (C. reshni hort. ex Tanaka), which have the capacity in crosses to generate individuals with great potential for use as rootstocks. In Brazil citrus orchards mostly use the rootstock 'Rangpur Santa Cruz' lime because it has agronomic characteristics of interest such as good productivity in periods of drought, rusticity and tolerance to certain diseases (Oliveira et al. 2008).

The aim of this study was to develop a strategy using water deficit induction to increase the frequency of hybrids in female parent with high rates of polyembryony, based on the 'Sunki' mandarin 'Tropical' selection.

\section{MATERIAL AND METHODS}

The experiment was developed in an anti-aphid greenhouse at Embrapa Cassava and Fruits, municipality of Cruz

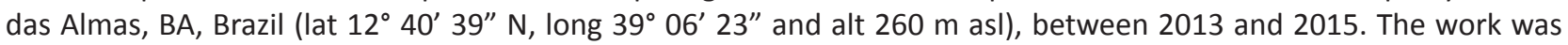
based on two varieties obtained by the Citrus Breeding Program of Embrapa Cassava and Fruits - CBP: Rangpur lime (C. limonia Osbeck) 'Santa Cruz' selection 'Rangpur Santa Cruz' lime and 'Sunki Tropical' mandarin. These varieties, which are commercially used as rootstocks for citrus growers, were grafted onto hybrid CSM x (RL x PT) - 059, where CSM refers to the common 'Sunki' mandarin, RL to 'Rangpur' lime and PT to the species $P$. trifoliata. This hybrid was also obtained by CBP.

The climatic variables, including air temperature, relative humidity and radiation, were monitored with the aid of a weather station installed at the experimental site. The average maximum and minimum temperature ranged $23^{\circ} \mathrm{C}$ within the four months of the pollinations. The relative humidity ranged from 91.4 to $40.0 \%$ between October and November (Figure 1). Gas exchanges were measured occasionally during the pollination period to confirm the physiological condition of the plants (Figure 2).

The soil consisted of a mixture of two parts of washed sand, one part of soil and two parts of Rendmax Citrus, a commercial pine bark substrate (2:1:2). The matric potential was estimated at the Soil Physics Laboratory of Embrapa Cassava and Fruit, based on the Van Genuchten (1980) model and humidity values.

The experiment was conducted in a completely randomized design using a factorial $2 \times 3$ arrangement $(2$ pre-selected genotypes $x 3$ stress intensities). The 3 stress intensity treatments each used 20 two-year-old plants per genotype packed in $45 \mathrm{~L}$ pots, which were covered with aluminium foil to prevent evaporation. 

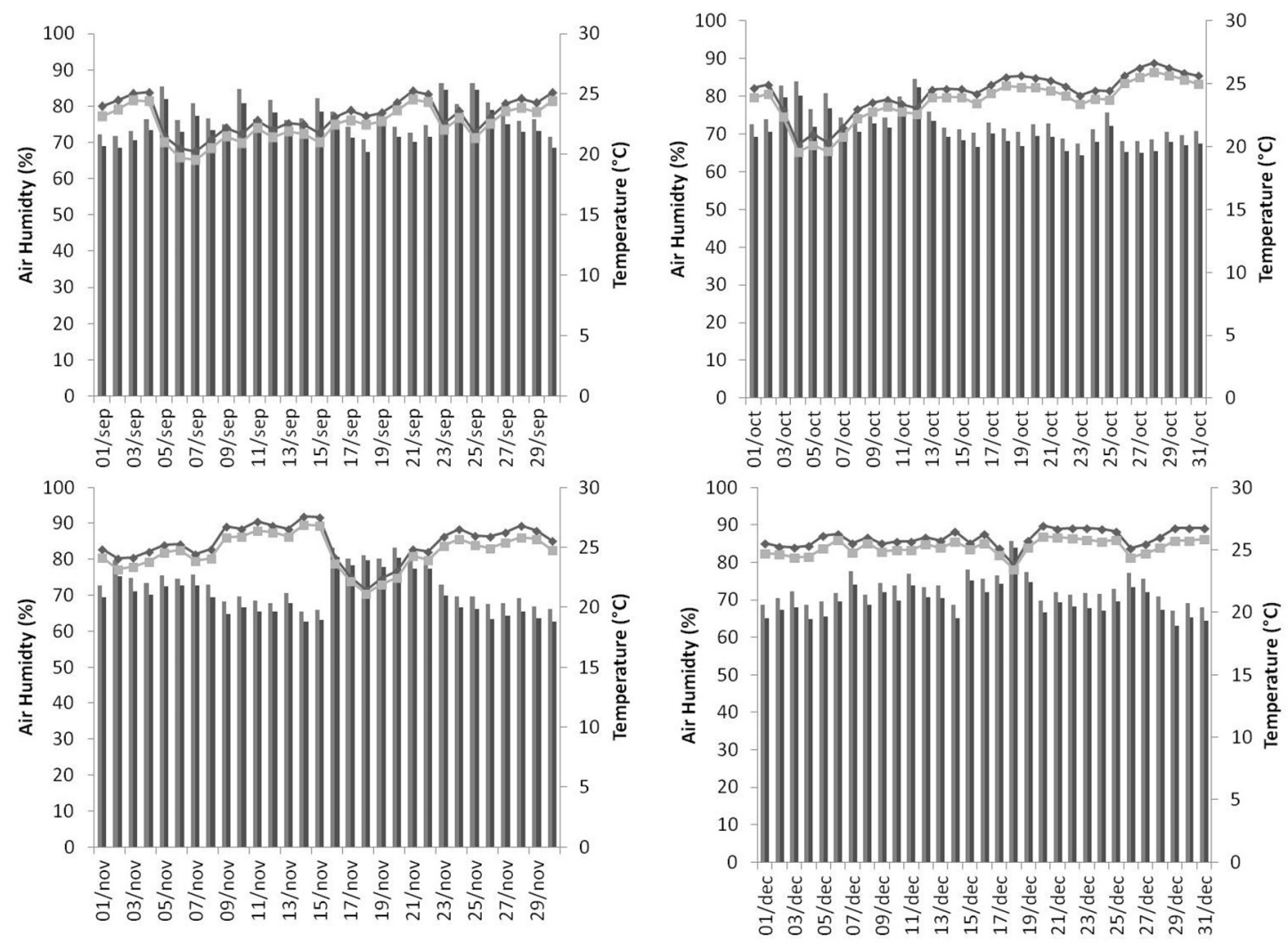

Figure 1. Weather conditions in an anti-aphid screen house between September and November 2014. Air relative humidity data (\%) and maximum and minimum temperature data are represented by bars and lines, respectively.

Before the beginning of the experiment, all the plants were kept at $100 \%$ of the pot capacity (PC). Before starting treatment, all the plants were subjected to an initial water deficit, with irrigation suspended to the wilting point, which occurred at approximately $10 \%$ of the available water fraction of the pot. After reaching this moisture level, 10 days were allowed to pass before irrigation was resumed to induce flowering. Following this 10-day period, the plants were hydrated to three levels of water stress, namely, severe, moderate and no water stress (control) at 20,40 and $100 \%$ of the $\mathrm{PC}$, respectively.

The soil water content was accessed using time domain reflectometry (TDR) probes constructed by hand and containing three stainless steel rods $0.003 \mathrm{~m}$ in diameter, $0.15 \mathrm{~m}$ long, spaced $0.022 \mathrm{~m}$ apart, insulated with polyester resin and fitted with RG58 coaxial cables ( $50 \mathrm{ohms}$ ) $0.75 \mathrm{~m}$ long. The plants were irrigated every two days based on the data obtained from the TDR readings, replacing only the amount of water required to stabilize the treatments.

During the plant flowering period, which occurred when the plants were three years old, gas exchanges were monitored for photosynthesis (A), transpiration (E) and stomatal conductance (gs) using an infrared gas analyzer (IRGA, LCpro-SD photosynthesis analyzer). During that period, the tops of 'Rangpur Santa Cruz' lime and 'Sunki Tropical' mandarin were pollinated with $P$. trifoliata (PT). The pollinations were always manually performed in the morning and identified for control. Between September and December 2014, approximately 30 flowers were pollinated in plants of each genotype. Some pollination events were aborted, and others were chopped due to the accumulation of fruit on the branch. After the pollination period, all the plants were irrigated to $100 \%$ of the PC. Routine cultivation treatments were carried out throughout the period for pest control.

Between April and June 2015, 299 fruits (Table 1) were collected: 141 'Rangpur Santa Cruz' lime and 158 'Sunki Tropical' mandarin derived from controlled pollinations that were distributed among the water deficit treatments. 


\section{LAH Almeida et al.}

The seeds were extracted, placed in whitewash solution (calcium hydroxide and magnesium hydroxide), then washed in running water to remove the mucilage and stored in the shade over newsprint to dry for one day. The seeds were separated and counted by genotype and treatment to determine the number of fruits per treatment and the number of seeds per fruit as well as the median size and weight of 50 seeds.

After drying, the seeds were classified as unviable when shrivelled, small when they reached one-third (1/3) to one-sixth (1/6) of normal size, and normal. The shrivelled seeds were discarded, and the normal ones were sown directly in seedbeds containing pine bark substrate. The small seeds were brought to the Tissue Culture Laboratory of Embrapa Cassava and Fruits for in vitro germination. After disinfection, the seeds were grown in test tubes containing approximately $10 \mathrm{~mL}$ of WPM medium, which was supplemented with $25 \mathrm{~g} \mathrm{~L}^{-1}$ of sucrose, solidified with $7 \mathrm{~g} \mathrm{~L}^{-1}$ of agar
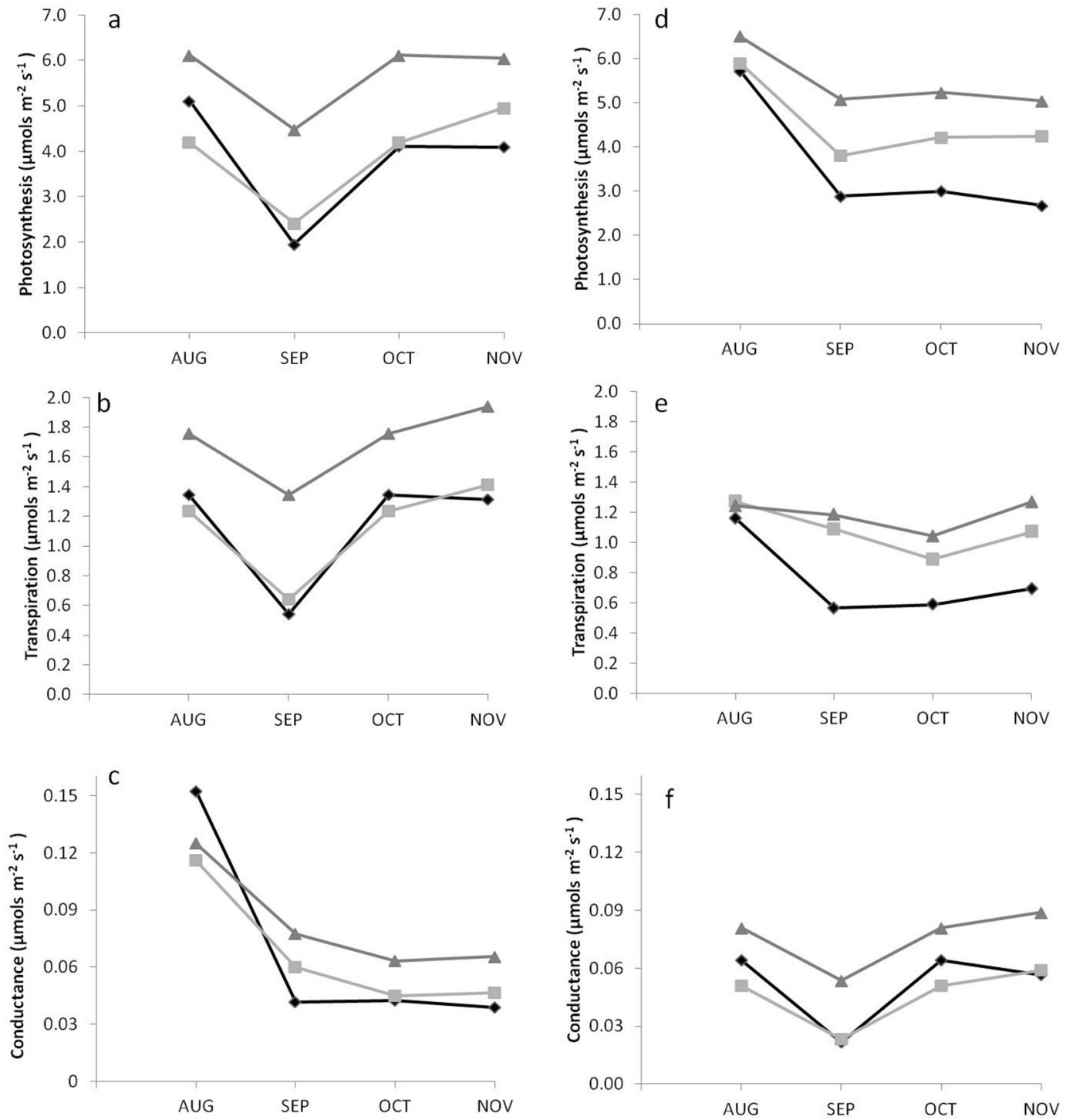

$$
\rightarrow-20 \%-40 \%-100 \%
$$

Figure 2. Photosynthetic rate, stomatal conductance and transpiration rate during water deficit treatments through the pollination period in genotypes 'Rangpur Santa Cruz' lime Citrus limonia Osbeck ( $a, b$ and c) and 'Sunki Tropical' mandarin C. sunki (Hayata) hort. ex Tanaka (d, e and f) 
and adjusted to $\mathrm{pH} 5.8$ before autoclaving. The tubes were kept in a growth room at a temperature of $27 \pm 1{ }^{\circ} \mathrm{C}$ and a photon flux density of $30 \mu \mathrm{mol} \mathrm{m} \mathrm{m}^{-2} \mathrm{~s}^{-1}$ under a 16-hour photoperiod for 45 days. Acclimatization was conducted in a greenhouse with controlled ventilation.

The effects of treatments in genotypes were evaluated through analysis of variance and the means compared by Tukey $(P<0.05)$ test using the statistical program genes (Cruz 2006).

\section{RESULTS AND DISCUSSION}

When compared with the control treatment ( $100 \%$ of the PC), an increase of the greatest magnitude in fruit number and, consequently, in the amount of available seed was observed in both genotypes for the most severe water deficit treatment, the $20 \%$ of PC treatment, followed by lesser increases for the $40 \%$ of PC treatment. These results confirm the observations of (Chica and Albrigo 2013), indicating that flowering in citrus is stimulated by water scarcity, as well as by low temperatures. These abiotic effects promote the differentiation of reproductive vegetative buds, increasing the number of flower buds and thus the development of more flowers and fruits (Santos et al. 2004, Iglesias et al. 2007). Another notable trend in both genotypes was a reduction in average seed weight with an increased severity of water deficit due to the emergence of lighter seeds in the $20 \%$ of PC treatment (Table 2).

In fruit plants, the induction of flowering after drought is common (Nakajima et al. 1993, Cuevas et al. 2008, Chang et al. 2014), and flowering is the determining phenological stage for productivity (García-Tejero et al. 2011). Responses to water stress are known to be associated with changes that lead to reproductive cycle manifestation, determining the cessation of sprout growth and the stimulation of reproductive bud formation, with the manifestation of this process influenced by the intensity and duration of stress, as well as the plant species (Cuevas et al. 2008, Ávila et al. 2012). The hydraulic discontinuity present in the basal structure of flowers and leaf sheaths causes the response amplitude to be greater in flowers than in other parts of the plant, even under stress. This slows the loss of water, ensuring the development of flowers and favouring the production of fruits (Saini 1997). However, as Sunki Maravilha seeds have become smaller and lighter by reducing the amount of water supplied in water deficit treatments. These results explain the increased frequency of hybrids found in this treatment. Lighter seeds may favor the zygotic embryo in competition with nucellars.

The number of seeds extracted was 1028 for 'Rangpur Santa Cruz' lime and 1653 for 'Sunki Tropical' mandarin. Twenty 'Rangpur Santa Cruz' lime seeds were classified as small seeds and were sent for in vitro germination. The shrivelled seeds were discarded, and the normal ones were planted directly in the seeding. For the normal 'Rangpur Santa Cruz' lime seeds that germinated, the observed frequency in the $20 \%$ PC treatment was $54.46 \%$ for hybrids and $45.53 \%$ for nucellar individuals, and in the 40 and $100 \%$ PC treatments, the observed frequencies were 64.21 and $52.63 \%$ for hybrids and 37.78 and $47.36 \%$ for nucellar seedlings, respectively (Table 1 ). The total seed number does not match the plant number due to polyembryony (some seeds generated more than two seedlings).

In the 'Sunki Tropical' mandarin genotype, 54 small seeds were found. Of these, only six derived from the $20 \%$ of PC treatment, generating four hybrid and two nucellar seedlings. Of the remaining small seeds, 30 originated from the $40 \%$ of PC treatment, generating eight hybrid and 22 nucellar seedlings. The normal seed in the $20 \%$ of PC treatment generated $21.75 \%$ hybrid and $78.24 \%$ nucellar seedlings, whereas the 40 and $100 \%$ of PC treatments formed 15.33 and

Table 1. Distribution of fruits and seeds in crossings under three moisture regimes and Seeds germinated by direct planting and the frequency of hybrid and nucellar seedlings for 'Rangpur Santa Cruz' lime and 'Sunki Tropical' mandarin genotypes

\begin{tabular}{|c|c|c|c|c|c|c|c|c|c|c|c|}
\hline \multirow{2}{*}{ Genotype } & \multirow{2}{*}{$\begin{array}{l}\text { Hydric } \\
\text { regime } \\
(\%)\end{array}$} & \multirow{2}{*}{$\begin{array}{c}\text { Fruit } \\
\text { number }\end{array}$} & \multirow{2}{*}{$\begin{array}{c}\text { Seed } \\
\text { number }\end{array}$} & \multirow{2}{*}{$\begin{array}{l}\text { Seed/ } \\
\text { fruit }\end{array}$} & \multirow{2}{*}{$\begin{array}{l}\text { Weight } \\
\text { of } 50 \\
\text { Seed }(\mathrm{g})\end{array}$} & \multirow{2}{*}{$\begin{array}{c}\text { Average } \\
\text { size }(\mathrm{mm})\end{array}$} & \multicolumn{2}{|c|}{ Total de seedlings } & \multirow{2}{*}{$\begin{array}{l}\text { Frequency of } \\
\text { hybrids (\%) }\end{array}$} & \multirow{2}{*}{$\begin{array}{c}\text { Frequency of } \\
\text { nucellar }(\%)\end{array}$} & \multirow{2}{*}{$\begin{array}{l}\text { Not germi- } \\
\text { nated seeds }\end{array}$} \\
\hline & & & & & & & Hybrid & Nucellar & & & \\
\hline \multirow{3}{*}{$\begin{array}{l}\text { 'Sunki Tropi- } \\
\text { cal' mandarin }\end{array}$} & 20 & 85 & 992 & 12 & 6.89 & 9.29 & 248 & 892 & 21.75 & 78.24 & 243 \\
\hline & 40 & 68 & 773 & 11 & 6.13 & 9.49 & 134 & 740 & 15.33 & 84.66 & 81 \\
\hline & 100 & 5 & 88 & 18 & 6.52 & 10.06 & 3 & 32 & 8.57 & 91.42 & 56 \\
\hline \multirow{3}{*}{$\begin{array}{l}\text { 'Rangpur } \\
\text { Santa Cruz' } \\
\text { Lime }\end{array}$} & 20 & 104 & 721 & 8 & 5.94 & 10.09 & 134 & 112 & 54.46 & 45.53 & 418 \\
\hline & 40 & 30 & 255 & 9 & 5.88 & 9.61 & 61 & 34 & 64.21 & 35.78 & 228 \\
\hline & 100 & 7 & 52 & 7 & 5.92 & 9.79 & 10 & 9 & 52.63 & 47.36 & 25 \\
\hline
\end{tabular}




\section{LAH Almeida et al.}

8.57\% hybrid seedlings, respectively, compared with 84.66 and $91.42 \%$ nucellar seedlings (Table 1 ).

In this study, it was found that water stress promoted the formation of hybrids in 'Sunki Tropical' female parent despite the high rate of polyembryony presented by this mandarin. Thus, water stress can be considered an important tool in stimulating the generation of zygotic individuals. The rootstock of 'Sunki Tropical' has behaved excellently in combination with various scions, which qualifies this rootstock for use in crosses aimed at obtaining hybrid rootstock varieties. In female parents, the genetic contribution of this rootstock to the formation of zygotic individuals has been observed for not only nuclear but also cytoplasmic genes.

The development of hybrid rootstock varieties, aiming to expand the gene pool present in commercial orchards, is of great value for improving the sustainability of citrus. With climate change and the increased incidence of many diseases and pests, the importance of developing methodologies that encourage the formation of hybrids using parents endowed with high horticultural value is evident. Among these, as already mentioned, are female parents whose seeds show high levels of polyembryony, with the restricted generation of hybrids due to the frequent formation of embryos of apomictic origin and the infrequent development of zygotic individuals. Kumar et al. (2014), studying the relation between abiotic stress and the manifestation of polyembryony, found that the development of nucellar cells occurs during the pre-anthesis phase, when the genes responsible for the formation of apomictic embryos would be expected to remain active. These authors comment that abiotic stress is linked to the signalling and triggering of gene expression cascades responsible for the production of reactive oxygen species (ROS) and $\mathrm{H}_{2} \mathrm{O}_{2}$. These products are responsible for the emergence of genetically competent groups of cells that form the nucellar embryos.

Soares Filho et al. (2014) demonstrated that the degree of polyembryony is inversely proportional to the number of hybrids formed from controlled crosses. This demonstration was based on the results of crosses involving female parents with different degrees of polyembryony, which ranged from $8 \%$ to nearly $100 \%$ in 'Sunki Florida' mandarin, as verified in the following mandarins: 'Sunki Tropical' (94\%), 'Sunki Maravilha' (97\%), 'Cleopatra' (98\%) and 'Dancy' (99\%) (C. tangerina Tanaka). Therefore, to ensure success in the production of hybrids, extreme situations exist warranting the use of monoembryonic female parents, whose seeds, as a rule, produce just one embryo of sexual origin (Chen et al. 2008, Soares Filho et al. 2002).

Studies to establish the frequency of hybrids in citrus are found in the literature in relation to the genetic improvement of culture stocks (Soares Filho et al. 2014, Soares Filho et al. 2007, Oliveira et al. 2000). In the present study, the frequency of hybrids generated in the cross 'Rangpur Santa Cruz' x P. trifoliata showed no significant variation between the 40 and $100 \%$ of PC water deficit treatments, with 64.21 and $52.63 \%$ hybrids, respectively (Table 1 ). These hybrid frequencies exceeded those found by Soares Filho et al. (2014) in a cross between 'Rangpur Santa Cruz', as female parent, and citrangequat 'Thomasville' [Fortunella margarita (Lour.) Swingle $\mathrm{x}$ citrange ( $C$. sinensis $\times$ P. trifoliata) 'Willits'], which produced a hybrid frequency of approximately $22 \%$. Although the male parents were different, it can be assumed that the higher frequency of hybrids detected in the current study reflects the limited environment for the development of roots, once the plants were grown in pots.

Comparing the crosses 'Rangpur Santa Cruz' lime $\times$ P. trifoliata and 'Sunki Tropical' mandarin $\times$ P. trifoliata, a significant increase in the frequency of hybrids was verified in the second cross with water stress treatment (Table 1), which may infer that water scarcity triggered survive mechanisms in this mandarin that favoured the perpetuation of its gene pool by generating variability, via hybridization, allowing the possible emergence of individuals with higher survivability in environments subject to this stress. Oliveira et al. (2015), working with the 'Rangpur Santa Cruz' lime and the 'Sunki Maravilha' mandarin, found that water stress caused changes in the abundance of proteins in the roots of both genotypes,

Table 2. Effect of drought treatments in size and average weight of 50 seeds in 'Rangpur Santa Cruz' lime and 'Sunki Tropical' mandarin genotypes

\begin{tabular}{|c|c|c|c|c|c|c|}
\hline \multirow[b]{2}{*}{ Genotype } & \multicolumn{2}{|c|}{$100 \%$} & \multicolumn{2}{|c|}{$40 \%$} & \multicolumn{2}{|c|}{$20 \%$} \\
\hline & Size $(\mathrm{mm})$ & Weight (g) & Size $(\mathrm{mm})$ & Weight (g) & Size $(\mathrm{mm})$ & Weight (g) \\
\hline 'Rangpur Santa Cruz' lime & 9.96abA* & $0.88 \mathrm{aB}$ & $9.36 \mathrm{bA}$ & $1.01 \mathrm{aA}$ & $10.06 \mathrm{aA}$ & $0.81 \mathrm{aA}$ \\
\hline 'Sunki Tropical' mandarin & $10.23 \mathrm{aA}$ & $2.29 \mathrm{aA}$ & $9.65 \mathrm{bA}$ & $1.67 \mathrm{bA}$ & $9.21 \mathrm{cA}$ & $1.63 c A$ \\
\hline
\end{tabular}

"Means followed by the same capital letters on the lines do not differ statistically from each other by F test and lower in columns belong to the same group by Tukey test at $5 \%$ probability. 
with major changes noticed in the mandarin. Santana-Vieira et al. (2016) found differences between these genotypes in their drought tolerance mechanisms, indicating that this behaviour of 'Sunki Maravilha' acts to ensure plant survival and to maintain active metabolic processes, doing so through the establishment of survive mechanisms with strategies that include tolerance to dehydration, the optimization of water use, and the reduction of photosynthesis and stomatal conductance. In the present study, the response of 'Sunki Tropical' mandarin to water stress favoured sexual embryo development, contrary to its behavior in the presence of a normal water supply, when this genotype, through seeds with a high rate of polyembryony, generated few zygotic embryos. These observations indicate that subjecting Citrus sunki to water scarcity triggered mechanisms that contributed to plant survival and gene pool preservation, whereas under the same conditions, $C$. limonia attempted to maintain its metabolism up to the limit of water availability.

To aid citrus breeding programmes, this study provides information that enables the generation of representative quantities of hybrids in controlled crosses using female parents with high levels of polyembryony subjected to a water deficit. This information was verified in crosses with 'Sunki Tropical' mandarin as the female parent, in which a hybrid frequency of approximately $22 \%$ was obtained with the application of relatively severe water stress through the $20 \%$ of PC treatment.

\section{ACKNOWLEDGEMENTS}

This research is supported by National Council for Scientific and Technological Development - CNPq and Fapesb. We are grateful to technical assistants Liziane Marques dos Santos and Maria Aparecida dos Santos de Jesus, for their kind support.

\section{REFERENCES}

Ávila C, Guardiola JL and Nebauer SG (2012) Response of the photosynthetic apparatus to a flowering-inductive period by water stress in Citrus. Trees - Structure and Function 26: 833-840.

Castle WS, Bowman KD, Grosser JW, Futch SH and Graham JH (2006) Florida citrus rootstock selection guide. 1. How to use the rootstock selection guide key to symbols. $3^{\text {rd }}$ edn, Horticultural Sciences Department, UF/IFAS Extension, Gainsville, p. 2-4.

Chang Y, Chang Y and Lin L (2014) Response of shoot growth, photosynthetic capacity, flowering, and fruiting of potted "Nagami" kumquat to different regulated deficit irrigation. Horticulture, Environment, and Biotechnology 56: 444-454.

Chen C, Lyon MT, O'Malley D, Federici CT, Gmitter J, Grosser JW and Gmitter FG (2008) Origin and frequency of $2 n$ gametes in Citrus sinensis $\times$ Poncirus trifoliata and their reciprocal crosses. Plant Science 174: 1-8.

Chica EJ and Albrigo LG (2013) Cool temperature and water deficit interact during floral induction in Citrus. Proceedings of the Florida State Horticultural Society 126: 45-50.

Cruz CD (2006) Programa Genes: Biometria. Editora UFV, Viçosa, 382p.

Cuevas J, Hueso JJ and Rodríguez MC (2008) Deficit irrigation as a tool for manipulating flowering date in Loquat (Eriobotrya japonica Lindl.). In Sorensen ML (eds) Agricultural water management research trends. Nova Science Publishers, New York, p. 237-253.

García-Tejero I, Durán-Zuazo VH, Arriaga-Sevilla J and Muriel-Fernández JL (2011) Impact of water stress on citrus yield. Agronomy for Sustainable Development 32: 651-659.
Grosser J, Graham J and Hoyte A (2007) Continued development of rootstocks tolerant of the phytophthora-diaprepes complex via greenhouse screening. Proceedings of the Florida State Horticultural Society 120: 103-109.

Hussain S, Curk F, Dhuique-Mayer C, Urban L, Ollitrault P, Luro F and Morillon R (2012) Autotetraploid trifoliate orange (Poncirus trifoliata) rootstocks do not impact clementine quality but reduce fruit yields and highly modify rootstock/scion physiology. Scientia Horticulturae 134: 100-107.

Iglesias DJ, Cercós M, Colmenero-Flores JM, Naranjo MA, Ríos G, Carrera E, Ruiz-Rivero O, Lliso I, Morillon F, Tadeo FR and Talon M (2007) Physiology of citrus fruiting. Brazilian Journal of Plant Physiology 19: 333-362.

Kumar V, Malik SK, Pal D, Srinivasan R and Bhat SR (2014) Comparative transcriptome analysis of ovules reveals stress related genes associated with nucellar polyembryony in citrus. Tree Genetics and Genomes 10: 449-464.

Nakajima Y, Susanto S and Hasegawa K (1993) Influence of water stress in autumn on flower induction and fruiting in young pomelo trees (Citrus grandis (L.) Osbeck). Journal of the Japanese Society for Horticultural Science 62: 15-20.

Nakano M, Kigoshi K, Shimizu T, Endo T, Shimada T, Fujii H and Omura M (2013) Characterization of genes associated with polyembryony and in vitro somatic embryogenesis in Citrus. Tree Genetics and Genomes 9: 795-803.

Oliveira RP, Novelli VM and Machado MA (2000) Frequência de híbridos em cruzamento entre tangerina "Cravo" e laranja "Pêra": Análise de marcadores morfológicos e RAPD. Pesquisa Agropecuária Brasileira 35: 1895-1903. 


\section{LAH Almeida et al.}

Oliveira RP, Soares Filho WS, Passos OS, Scivittar OWB and Rocha PSG (2008) Porta-enxertos para citros. Embrapa Clima Temperado, Pelotas, 45p. (Documento, 226).

Oliveira TM, Silva FR, Bonatto D, Neves DM, Morillon R, Maserti BE, Coelho Filho MA, Costa MGC, Pirovani CP and Gesteira AS (2015) Comparative study of the protein profiles of Sunki mandarin and Rangpur lime plants in response to water deficit. BMC Plant Biology 15: 69.

Ollitrault P and Navarro L (2012) Citrus. In Badenes ML and Byrne DH (eds) Fruit breeding. Springer, New York, p. 623-662.

Passos OS, Peixouto LS, Santos LC, Caldas RC and Soares Filho WS (2006) Caracterização de híbridos de Poncirus trifoliata e de outros porta-enxertos de citros no Estado da Bahia. Revista Brasileira de Fruticultura 28: 410-413.

Saini HS (1997) Effects of water stress on male gametophyte development in plants. Sex Plant Reproduction 10: 67-73.

Santana-Vieira DDS, Freschi L, Almeida LAH, Neves DM, Moraes DHS, Santos LM, Bertolde FZ, Soares Filho WS, Coelho Filho MA and Gesteira AS (2016) Survival strategies of citrus rootstocks subjected to drought. Scientific Reports 6: 38775.
Santos CH, Klar AE, Grassi Filho H, Rodrigues JD and Pierre FC (2004) Indução do florescimento e crescimento de tangerineira "Poncã" (Citrus reticulata Blanco) em função da irrigação e da aplicação de paclobutrazol. Revista Brasileira de Fruticultura 26: 8-12.

Siviero A, Cristofani M and Machado MA (2003) QTL mapping associated with rooting stem cuttings from Citrus sunki vs. Poncirus. Crop Breeding and Applied Biotechnology 3: 83-88.

Soares Filho WDS, Ledo CADS, Quintela MP, Mattos LA, Passos OS and Souza ADS (2007) Cruzamentos em citros: frequência e vigor de híbridos. Revista Brasileira de Fruticultura 29: 393-398.

Soares Filho WS, Souza U, Ledo CAS, Santana LGL and Passos OS (2014) Poliembrionia e potencial de obtenção de híbridos em citros. Revista Brasileira de Fruticultura 36: 950-956.

Soares-Filho WS, Diamantino MSAS, Moitinho EDB, Cunha-Sobrinho AP and Passos OS (2002) "Tropical ": Uma Nova Seleção De Tangerina "Sunki ." Revista Brasileira de Fruticultura 24: 127-132.

Van Genuchten MT (1980) A closed-form for predicting the hydraulic conductivity of unsaturated soils. Soil Science Society of American Journal 41: 892-898. 